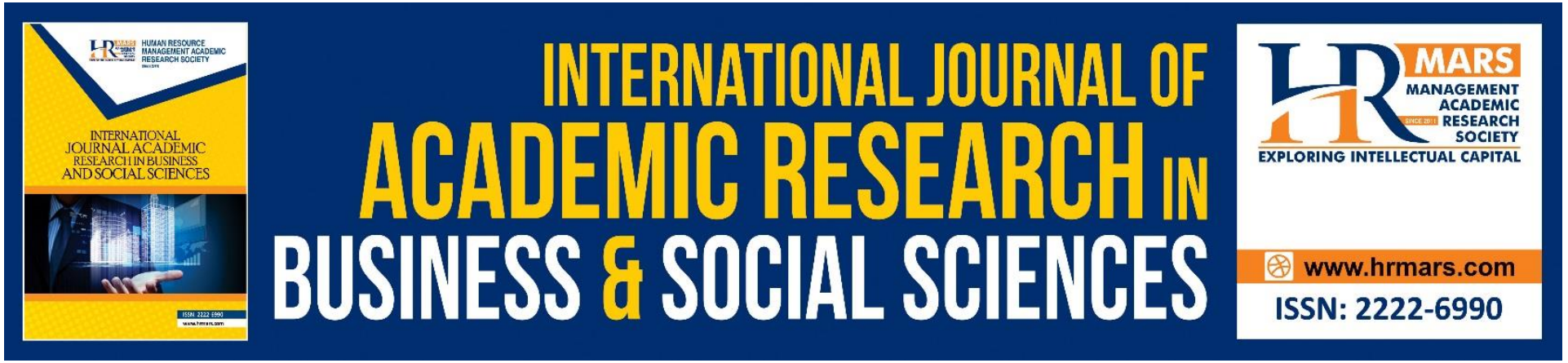

\title{
The Effects of Visual Merchandising on Consumer's Willingness to Purchase in the Fashion Retail Stores
}

\section{Edward Probir Mondol, Narjes Ahmed Salman, Abu Obida Rahid, Asif} Mahbub Karim

To Link this Article: http://dx.doi.org/10.6007/IJARBSS/v11-i7/10469

DOI:10.6007/IJARBSS/v11-i7/10469

Received: 16 May 2021, Revised: 19 June 2021, Accepted: 01 July 2021

Published Online: 12 July 2021

In-Text Citation: (Mondol et al., 2021)

To Cite this Article: Mondol, E. P., Salman, N. A., Rahid, A. O., \& Karim, A. M. (2021). The Effects of Visual Merchandising on Consumer's Willingness to Purchase in the Fashion Retail Stores. International Journal of Academic Research in Business and Social Sciences, 11(7), 386-401.

Copyright: @ 2021 The Author(s)

Published by Human Resource Management Academic Research Society (www.hrmars.com)

This article is published under the Creative Commons Attribution (CC BY 4.0) license. Anyone may reproduce, distribute, translate and create derivative works of this article (for both commercial and non-commercial purposes), subject to full attribution to the original publication and authors. The full terms of this license may be seen at: http://creativecommons.org/licences/by/4.0/legalcode

Vol. 11, No. 7, 2021, Pg. 386 - 401

Full Terms \& Conditions of access and use can be found at http://hrmars.com/index.php/pages/detail/publication-ethics 


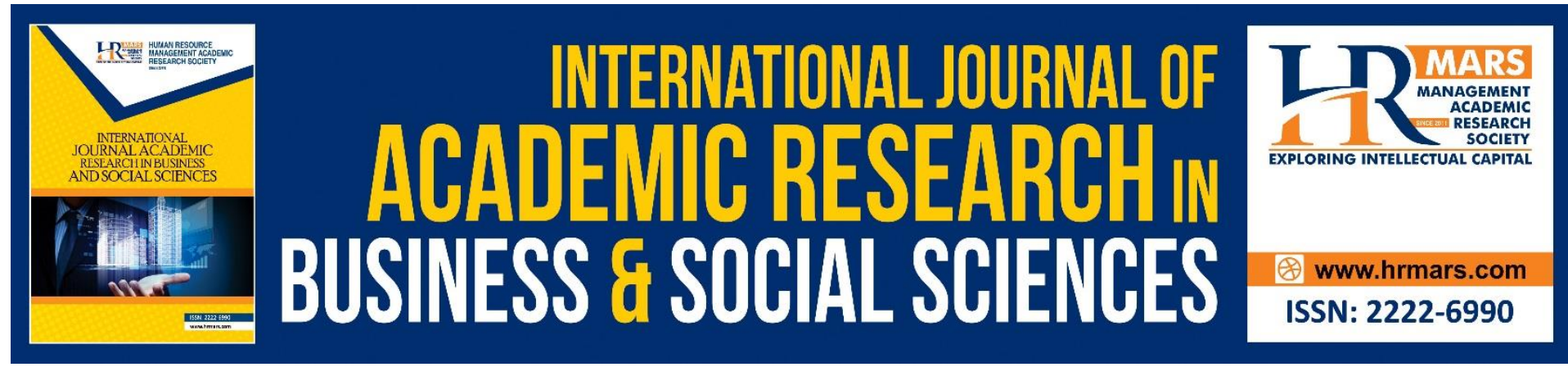

\title{
The Effects of Visual Merchandising on Consumer's Willingness to Purchase in the Fashion Retail Stores
}

\author{
Edward Probir Mondol ${ }^{1}$, Narjes Ahmed Salman², Abu Obida \\ Rahid $^{3}$, Dr. Asif Mahbub Karim ${ }^{4}$ \\ ${ }^{1}$ Principal and Chief Learning Evangelist, Global Academy of Holistic Leadership and \\ Coaching Inc, Canada, '2Lecturer, English, English Language Center, University of Bahrain. \\ ${ }^{3}$ Lecturer, Faculty of Business Administration, CCN University of Science \& Technology, \\ Kotbari, Cumilla, Bangladesh, ${ }^{4}$ Professor and Dean Binary Graduate School, Binary \\ University, Malaysia.
}

\begin{abstract}
The art of visual displays and the arrangement of merchandising solutions in a shop is virtual merchandising, which improves layout and design, increases development, sales and thereby profitability. Visual merchandising affects the shopping experience directly, making it relevant for retailers to ensure an efficient nature of their business climate. The main aspiration of this study is to figure out the visual merchandising elements which influence on an individual's purchase intention. A sample of 356 respondents available at different fashion stores in Malaysia was used to get the study outcomes following the quantitative analysis. The Smart PLS 3.0 was used for analysing the data. This study claims that there is a positive and significant relationship between store layout and consumer's intention to purchase. Then, a positive and significant relationship is also found between product display and consumer's intention to purchase. Furthermore, a positive and significant relationship is found between colour \& lighting and consumer's intention to purchase. Moreover, a positive and significant relationship is not found between cleanliness and consumer's intention to purchase. The outcomes of this study will help the policy makers, government and entrepreneurs to make their fashion stores gorgeous. This study would enable fashion retailers to build more insightful, engaging online shops, which will then boost retail sales online.
\end{abstract}

Keywords: Visual Merchandising, Consumer Behaviour, Intention to Purchase, Malaysia, Sem, Survey

\section{Introduction}

In the retail industry, visual merchandising plays a significant part. This enhances goods, promotes brands, boosts traffic and purchases, provides visual excitement by strategically placed and illuminated focal destinations in an atmosphere which usually defines and publishes overall personality and image in businesses and shops. It is all the consumers see and sound in a shop that excites their curiosity and wish (Bhatti \& Latif, 2014; Mehta \& Chugan, 2014; Gudonavičienė \& Alijošienė, 2015; Bhattacharjee et al., 2020). In other words, 
a store must draw and catch the attention of consumers and encourage them to buy the goods. An efficient visual merchandising approach can allow supermarkets to compete and compete within the industry (Khaled et al., 2019). Visual merchandising features in fashion stores are extremely important. It entices potential customers to visit the store and enhances their buying intent (Hefer \& Cant, 2013; Cant \& Hefer, 2014; Polas et al., 2017; Mehta \& Chugan, 2019). The word fashion refers to clothing, shoes, and footwear. The growth of fashion industries can be reflected in societal changes in lifestyle and purchasing intentions. The fashion industry is no longer mostly concerned with women, but it has expanded its services to men as men's fashion awareness has grown (Polas et al., 2017; Widyastuti, 2018; Bhattacharjee et al., 2018).

Furthermore, through social images and affiliations, powerful visual merchandising leads to a distinguished supermarket brand (Thomas et al., 2018). The psychological aspects of shopping experience graphics influence brand recognition (Yaoyuneyong et al., 2014; Kpossa \& Lick, 2020). A holistic approach to visual merchandising views retail architecture, merchandise presentation means as strategies to coordinate product interactions and capture shoppers' attention in apparel stores (Rathee \& Prakash, 2017; Polas et al., 2018a). Furthermore, one of the most important functions of visual merchandising is to communicate the brand and its proposition to comparable potential audiences in all markets. It distinguishes the merchandise and the supermarket brand from competitors offering related items (Katrandjiev \& Velinov, 2014; Polas et al., 2021). Consumer impressions of visual merchandising will pique their interest and lead to further in-store merchandise experimentation (Iberahim et al., 2019). Mannequins used in visual merchandising provide knowledge that contributes to customers' psychological understanding of goods as well as their social acceptability (Cant \& Wiid, 2020). When executed effectively, visual merchandising upgrades deals and profits (Gigoła, 2014; Štulec et al., 2016; Dash \& Akshaya, 2016; Bhattacharjee et al., 2018; Afshar et al., 2019; Polas \& Afshar Jahanshahi, 2020).

The main objective of this study is to figure out visual merchandising elements in a store which leads an individual to purchase. Its other aim is to recognize the current approaches used by supermarkets to improve their visual merchandising. The research was successful in achieving all of its objectives, as shown by the creation of a visual merchandising strategy that provides players in the retail sector with a competitive advantage. This study reveals that there are positive and significant relationship between store layout, product display, and cleanliness with consumer's intention to purchase in the fashion stores. This introduction is accompanied by the literature review, methodology, findings, conclusion as well as limitations and future studies.

\section{Literature Rev iew and Hypotheses Development Store Layout and Intention to Purchase}

The authors predict that store design affects consumers' purchase intentions in the first hypothesis. In general, store design is critical in attracting customers. Nowadays, shop managers face a massive task when it comes to store design (Singh et al., 2014; Behera \& Mishra, 2017). The complexity of this task lies in the relationship between sale classifications as well as the impact it has on customer spatial Behaviour and in-store traffic. A detail layout facilitates shopping, which is essential when a fashion store is selected (Alawadhi \& Yoon, 2016; Polas et al., 2018; Rahmawati et al., 2018). Mode supermarket chains promoting onestop shopping format will cater to consumers who have a sense of time and commitment (Malik \& Guptha, 2014; Behera \& Mishra, 2017). 
Typically, customers like to shop at retailers where they can quickly select the items they need. The shoppers' attention would be drawn to the store's architecture if it is wellorganized. When customers develop a good outlook toward a shop, they will return time and time again. Often, they would spread the word about the shop layouts to their loved ones, which eventually increases the sales of those retailers (Dhurup \& Mafini, 2015; Shamsher, 2016; Polas et al., 2020). Elbers (2016) proposed that customers may be influenced to buy by the layout itself, and that a good store model empowers any customer to go beyond whatever number shows as being permitted. The results from a study conducted by Wilson et al. (2019), suggest that retail has a considerable effect and that customers want stores to use whatever it takes to develop a layout that decreases wasteful shopping progress and operation. It has also been recorded that consumers have more power than on their roof on the floor of a shop. Thus, author hypothesize that,

H1: There is a positive and significant relationship between store layout and consumer purchasing intention in fashion retail stores.

\section{Product Display and Intention to Purchase}

Authors predict in the second hypothesis that show would influence the customer purchasing intention. The product show was recognised in a research conducted by Park et al. (2014) as a boosts shop, an advertising tactic used in drive purchasing. It is said that displays will build up the speed of random purchases in dealer shops because buyers are usually concentrated and seen at the level of their eyes (Hsu et al., 2017; Bashir et al., 2019). In their analysis, it was also found that displays are one of the most convincing variables when shopping spontaneously (Shaouf et al., 2016; Choshaly, 2017; Polas \& Afshar Jahanshahi, 2020). Authors predict in the second hypothesis that show would influence the customer purchasing intention. The product show was recognised in a research conducted by Yim et al. (2014) as a boosts shop, an advertising tactic used in drive purchasing. It is said that displays will build up the speed of random purchases in dealer shops because buyers are usually concentrated and seen at the level of their eyes. In their analysis, it was also found that displays are one of the most convincing variables when shopping spontaneously (Li et al., 2015; Hussain \& Ali, 2015). Iberahim et al. (2018) explained the considerable effect of commodity shelving on the intent to purchase. The product selling is influenced both by the height of the product and the number of lines in the shop. In a moderate fashion shop, just thirty-five of the likely several thousand individual pieces will be chosen by the average buyer (Lee \& Lee, 2015; Polas, et al., 2020). In addition, commonly bought goods should never be located in neighbouring areas but should be distributed all over the supermarket so that the chances of purchasing the intermediate items are increased (Park et al., 2015; Jain, 2019; Polas et al., 2021). Cautious use of high demand lines will help shoppers to move to areas of the shop: thus, high-income motivational buying lines should be closed to ordinary goods. More than $50 \%$ of business buyers' orders were pre-arranged and the remainder are usually enhanced by the showcase in the shop. Customers should be able to access products (Rahim et al., 2016; Yan et al., 2016; Abdul Latiff et al., 2016; Findling et al., 2018; Polas et al., 2018a). This means enticing product display affects the purpose of buying the consumer. Authors hypothesize that,

H2: There is a positive and significant relationship between product display and consumer purchasing intention in fashion retail stores. 


\section{Colour-Lighting and Intention to Purchase}

In the fourth hypothesis, authors anticipate that colour-lighting in a fashion shop affects the intention of purchasing by consumers. During the period corresponding to physiological and mental colour effects, several studies have been conducted. Warm colours (red and yellow) had an opposite physiological and intellectual effect as well as cold colours (blue and green) (Dash \& Akshaya, 2016; Nasim \& Shamshir, 2018). Red or warm colours were, for example, seen as linked to increased blood pressure, breathing rate and timing of the blink of the eye (Ariffin et al., 2017; Polas et al., 2021). The effects of colour shading on the shop design were researched by Hefer \& Nell (2015). The results revealed that subjects were actually drawn, regardless of colour tilt, to warm colour (yellow and red), but red retail environments were incomprehensibly disagreeable, negligible, tense and less attractive than the cold (green and blue) setting. The red environment can invigorate both physiologically and mental buyers and then weaken buying considerations and procurement choices he conjectured (Yildirim et al., 2015; Massara, 2020).

Moreover, lighting had a major influence on the world so brilliantly illuminated spaces were more stirring than tiny lit rooms (Van Niekerk et al., 2016; Lee \& Lee, 2021). Hefer \& Nell (2015) observed, under "brilliant" light conditions, that customers reviewed and dealt with more of the things than under "bad" light conditions. With regard to the North American Illuminating Engineering Society, the manual said that "the key objectives typical in product lighting are to attract the buyer, start buying and promote the culmination of the offer" (Borisuit et al., 2015; Figueiro et al., 2018). The IES says that lighting designers must provide a "friendly and safe atmosphere for doing business" while lighting marketing spaces (de Korte et al., 2015; Pandharipande \& Newsham, 2018; Polas et al., 2018b). A more attractive store with a better lit product could attract buyers, Park et al. (2015) to see the shop, expect and purchase a better product. Their studies suggest that the management of the in-store additional presentation lighting by a retailer can achieve a significant increase in customer participation of the store display goods. The way a shop is lit is very sensitive to customers (Parsons \& Descatoires, 2016; Nell, 2017; Jones \& Bartlett, 2018; Polas et al., 2018b). They have a greater effect than structures and signs on lighting. Thus, authors hypothesize that, H3: There is a positive and significant relationship between colour \& lighting atmosphere and consumer purchasing intention in fashion retail stores.

\section{Cleanliness and Intention to Purchase}

Authors agree in the fourth hypothesis that cleanliness attracts the consumer purchase intention. Cleanliness is generally one of the most important aspects of the visual market. The clean environment is meaningful in terms of shops for customers. Consumers typically tend to be sterile and clean physically (Hussain \& Ali, 2015; Syahrivar, 2017; Imelia \& Ruswanti, 2017; Polas et al., 2018a). Cleanliness in retail gives an emotional reaction from shoppers who will buy from those stores later. It must be sexy and brilliant. Clean air affects the buying desire of customers. It strikes the brain of the customer around shops (Loan et al., 2015; Maharani et al., 2020). Market experience is enriched because it is linked to market psychology. Harris et al. (2016) have shown that cleanliness is the ultimate major shopping attribute for both regular and casual retail customers in general. Sarwar et al. (2020) said the clean shops would create images of cleanliness, satisfaction or extravagance. The appearance of the store (such as a shop is fine, confident, pleasant etc.) will then be depicted as the general look and the mental image structure inspired within the consumer. Thus, author hypothesize that, 
H4: There is a positive and significant relationship between Cleanliness and consumer purchasing intention in fashion retail stores.

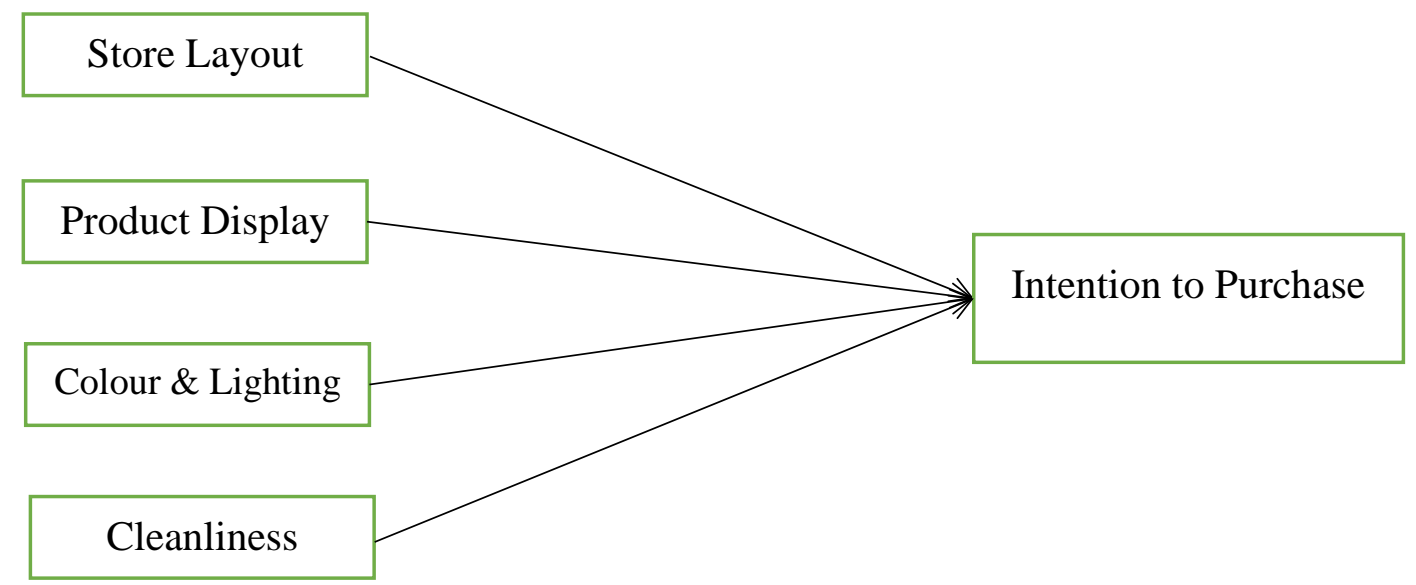

Figure 1: The Framework of the study

\section{Research Methodology}

In this study, a positivist research approach was used in place of a hypothetic deductive approach (Polas \& Raju, 2021). Simple random sampling technique was used following crosssectional study. In this study, the researchers used the survey approach to collect data. The survey was carried out among respondents available in Kualalumpur, Malaysia during the month of November, 2020- December, 2020. The questionnaire was the main instrument in this study, which consisted of twenty-two questions, was the key tool in this study. The first five questions were to measure the signified control variables, namely gender, age, marital status, educational level monthly income and next seventeenth questions are used to measure independent, mediator and dependent variable, namely store layout, product display, and colour \& lighting, cleanliness as independent variable, intention to purchase as dependent variable. The Likert scale is used as a measurement set for 17 questions (1-17, Section B), ranging from strongly disagree (1) to strongly agree (5). As close-ended questions, the first five questions (demographical). In this research, software Smart PLS (SEM) 3.0 was used according to the quantitative approach to analyse primary data.

\section{Measurement Scale}

\section{Store Layout}

Here, authors have used three items for measuring the store layout. These items are "The store layout represents the local culture, the interior design is visually well appealing, and the store layout allows all to move around easily". The reliability assessment resulted in a Cronbach's alpha of 0.789 for this three-item store layout scale.

\section{Product Display}

Here, authors have used three items for measuring the product display. These items are "The products are well-organized, the products are easy to be visible, and I feel convenient to find products in the store". The reliability assessment resulted in a Cronbach's alpha of 0.869 for this three-item product display scale. 


\section{Colour \& Lighting}

Here, authors have used three items for measuring the colour \& lighting. These items are "The Colours and Lighting of the store creates a pleasant atmosphere, the Colours and Lighting of the store are attractive, and the Colours and Lighting of the store are catchy". The reliability assessment resulted in a Cronbach's alpha of 0.887 for this three-item colour \& lighting scale.

\section{Cleanliness}

Here, authors have used three items for measuring the cleanliness. These items are "The store is neat and clean, the store is in hygienic manner, and the store is at the optimum temperature". The reliability assessment resulted in a Cronbach's alpha of 0.741 for this threeitem cleanliness scale.

\section{Intention to Purchase}

Here, authors have used four items for measuring the consumer purchasing intention. These items are "It is likely that I will transact with this fashion store in the near future, Given the chance, I intend to purchase products from this fashion store, Given the chance, I predict that I should visit this fashion store in the future, the performance of the fashion store fulfils my expectation". The reliability assessment resulted in a Cronbach's alpha of 0.898 for this fouritem consumer purchasing intention scale.

\section{Results}

The outcomes are called the brain of any study. Table 1 shows the respondent's demographic profile. In this study, a sample of 356 respondents was available at Kualalumpur in Malaysia used for getting the study results. As found in Table 1, 65.17 per cent of respondents were male and 34.83 per cent of respondents were female. After that, 15.73 per cent of respondents were between the age of 18-22 years, 28.93 per cent of respondents were between the age of 23-27 years, 34.27 per cent of respondents were between the age of 2832 years, 11.24 per cent of respondents were between the age of 33-37 years and 7.02 per cent of respondents were 38 years or above. Besides, 64.04 per cent of respondents were single and 31.18 per cent of respondents were married. Moreover, 29 per cent of respondents were elementary school degree holder, 27.53 per cent of respondents were junior high school degree holder, 52.81 per cent of respondents were high school or vocational degree holder and 11.52 per cent of respondents were college or university education degree holder. After that, 59.27 percentage of respondent's monthly income was between 500-1000 USD, 12.36 percentage of respondents' monthly income was between 1001-1500 USD, 13.76 percentage of respondents' monthly income was between 1501-2000 USD, 9.27 per cent of the respondent's monthly income was between 2001-2500 USD and 5.34 percentage of respondents' monthly income was 2001 USD or above. 
INTERNATIONAL JOURNAL OF ACADEMIC RESEARCH IN BUSINESS AND SOCIAL SCIENCES Vol. 11, No. 7, 2021, E-ISSN: 2222-6990 @ 2021 HRMARS

Table 1: Respondent's Demographic Profile

\begin{tabular}{|c|c|c|c|c|c|}
\hline $\begin{array}{l}\text { Characteristic } \\
\mathrm{S}\end{array}$ & Frequency & Percentage & Characteristics & Frequency & Percentage \\
\hline \multicolumn{3}{|l|}{ Gender } & \multicolumn{3}{|l|}{ Education Level } \\
\hline Male & 232 & 65.17 & Elementary school & 29 & 8.15 \\
\hline Female & 124 & 34.83 & Junior high school & 98 & 27.53 \\
\hline \multicolumn{3}{|l|}{ Age } & $\begin{array}{l}\text { High school or } \\
\text { vocational school }\end{array}$ & 188 & 52.81 \\
\hline 18-22 Years & 56 & 15.73 & $\begin{array}{l}\text { College or university } \\
\text { education }\end{array}$ & 41 & 11.52 \\
\hline 23-27 Years & 103 & 28.93 & \multicolumn{3}{|c|}{ Monthly Income (US Dollar) } \\
\hline 28-32 Years & 122 & 34.27 & $500-1000$ & 211 & 59.27 \\
\hline 33-37 Years & 40 & 11.24 & $1001-1500$ & 44 & 12.36 \\
\hline 38 or Above & 25 & 7.02 & $1501-2000$ & 49 & 13.76 \\
\hline \multicolumn{3}{|l|}{ Marital Status } & $2001-2500$ & 33 & 9.27 \\
\hline Single & 228 & 64.04 & 2501 or above & 19 & 5.34 \\
\hline Married & 111 & 31.18 & & & \\
\hline Divorced & 17 & 4.78 & & & \\
\hline
\end{tabular}

Measurement of Model Assessment

Table 2: Measurement of Model Assessment

\begin{tabular}{|l|l|l|lll|l|}
\hline \multirow{3}{*}{ Constructs } & & Loading & & & $\begin{array}{l}\text { R- } \\
\text { Square }\end{array}$ \\
\hline & Items & & AVE & CR & Alpha & Sqyout (SL) \\
& SL1 & 0.897 & & & & \\
& SL2 & 0.727 & 0.794 & 0.876 & 0.789 & \\
& SL3 & 0.882 & & & & \\
\hline \multirow{5}{*}{ Product Display (PD) } & PD1 & 0.832 & & & & \\
& PD2 & 0.93 & 0.794 & 0.92 & 0.869 & \\
& PD3 & 0.911 & & & & \\
\hline \multirow{5}{*}{ Colour \& Lighting (CL) } & CL1 & 0.943 & & & & \\
& CL2 & 0.840 & 0.817 & 0.931 & 0.887 & \\
& CL3 & 0.926 & & & & \\
\hline & C1 & 0.691 & & & & \\
& C2 & 0.887 & 0.66 & 0.852 & 0.741 & \\
& C3 & 0.845 & & & & \\
\hline \multirow{5}{*}{ Intention to Purchase } & IP1 & 0.778 & & & & \\
& IP2 & 0.884 & & & & \\
& IP3 & 0.879 & 0.712 & 0.925 & 0.898 & 0.913 \\
& IP4 & 0.827 & & & & \\
& IP5 & 0.847 & & & & \\
\hline
\end{tabular}

Model assessment is one of the crucial parts for any study. It becomes easier by running SEM. Table 2 shows the measurement of model assessment where the value of CR and Cronbach's Alpha is above 0.70 and the value of factor loadings is above 0.60 which are the suggested or 
an accepted range. However, $\mathrm{R}^{2}$ specifies the values of the variances of the endogenous variable(s). Here, Intention to Purchase is demonstrated by a large effect (0.913 or $91.3 \%$ ) with exogenous variables.

Table 3: Predictive Relevance

\begin{tabular}{|c|c|c|}
\hline Constructs & Intention to Purchase $\left(\left(f^{2}\right)\right.$ & $\mathbf{Q}^{2}$ \\
\hline Cleanliness & 0.05 & 0.335 \\
\hline Colour \& Lighting & 0.187 & 0.561 \\
\hline Intention to Purchase & & 0.537 \\
\hline Product Display & 0.075 & 0.527 \\
\hline Store Layout & 0.378 & 0.401 \\
\hline
\end{tabular}

Large effect $>0.34$; Medium effect $>0.14$; Small effect $>0.01$ (Cohen,

1988)

Table 3 shows that cleanliness and product display have a small effect on intention to purchase. Then, colour \& lighting has a medium effect on intention to purchase. Moreover, store layout has a large effect on intention to purchase. Value of each latent variable is greater than zero which indicates predictive relevance of the constructs. Overall, the proposed study model is best fit with study objectives and hypotheses.

\section{Discriminant validity: Fornell-Larcker criterion}

Investigating the discriminant validity of any study model, Fornell-Larker Criterion is very popular among researchers. Table 4 below shows the discriminate validity of the study. To assess the discriminate validity for measuring the model, Fornell-Larcker criterion was smeared in this study. Furthermore, the square root of the AVE (in bold) of all variables defines the highest within a range of 0.812-0.904. In this way, it well understands that discriminant validity is remained between variables and recognized for this estimated model of the study.

Table 4: Discriminant Validiy- Fornell-Larcker Criterian

\begin{tabular}{|l|llllll|}
\hline SL. No. & Constructs & 1 & 2 & 3 & 4 & 5 \\
\hline 1 & Cleanliness & 0.812 & & & & \\
2 & Colour \& Lighting & 0.688 & 0.904 & & & \\
3 & Intention to Purchase & 0.654 & 0.856 & 0.844 & & \\
4 & Product Display & 0.689 & 0.781 & 0.785 & 0.891 & \\
5 & Store Layout & 0.657 & 0.675 & 0.501 & 0.728 & 0.839 \\
\hline
\end{tabular}

*The diagonal are the square root of the AVE (in bold) of the latent variables and indicates the highest in any column or raw

\section{Structural Model Assessment}

Figure 2 shapes the structural model assessment of the study. Author used the bootstrapping process with a resample 500 was also implemented to find out the $t$-values and $R$ square. 


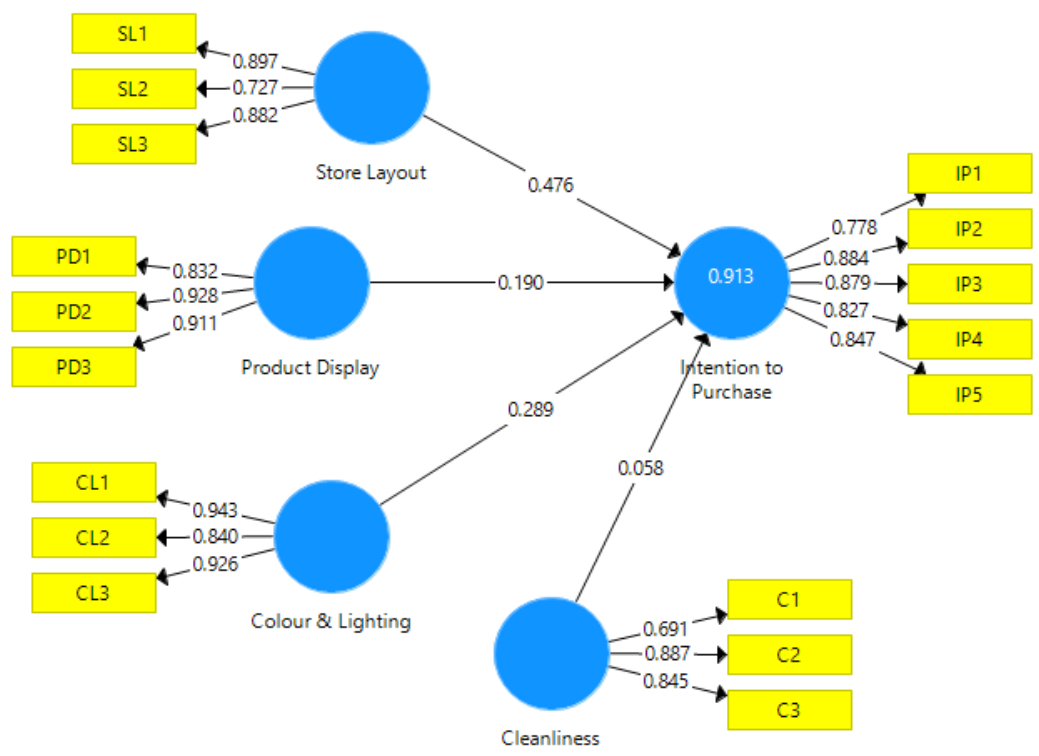

Figure 2: Standardized results of SEM calculations

\section{Hypotheses Testing}

Table 5: Result of Direct and Indirect Effect Hypotheses

\begin{tabular}{|c|c|c|c|c|c|c|}
\hline $\begin{array}{l}\text { Hypothese } \\
\text { s }\end{array}$ & Relationship & $\begin{array}{l}\text { Std } \\
\text { Beta }\end{array}$ & $\begin{array}{l}\text { Std } \\
\text { Error }\end{array}$ & $\begin{array}{l}\mathrm{t}- \\
\text { value }\end{array}$ & $\begin{array}{l}\mathrm{p}- \\
\text { value }\end{array}$ & Decision \\
\hline $\mathrm{H} 1$ & $\begin{array}{l}\text { Store Layout } \rightarrow \text { Intention to } \\
\text { Purchase }\end{array}$ & $\begin{array}{l}0.47 \\
1\end{array}$ & 0.090 & $\begin{array}{l}5.30 \\
7\end{array}$ & $\begin{array}{l}0.00 \\
0\end{array}$ & $\begin{array}{l}\text { Supporte } \\
\text { d }\end{array}$ \\
\hline $\mathrm{H} 2$ & $\begin{array}{l}\text { Product Display } \rightarrow \text { Intention to } \\
\text { Purchase }\end{array}$ & $\begin{array}{l}0.18 \\
7\end{array}$ & 0.061 & $\begin{array}{l}3.11 \\
0\end{array}$ & $\begin{array}{l}0.00 \\
2\end{array}$ & $\begin{array}{l}\text { Supporte } \\
\text { d }\end{array}$ \\
\hline H3 & $\begin{array}{l}\text { Colour \& Lighting } \rightarrow \text { Intention to } \\
\text { Purchase }\end{array}$ & $\begin{array}{l}0.29 \\
3\end{array}$ & 0.070 & $\begin{array}{l}4.13 \\
3\end{array}$ & $\begin{array}{l}0.00 \\
0\end{array}$ & $\begin{array}{l}\text { Supporte } \\
\text { d }\end{array}$ \\
\hline $\mathrm{H} 4$ & $\begin{array}{l}\text { Cleanliness } \rightarrow \text { Intention to } \\
\text { Purchase }\end{array}$ & $\begin{array}{l}0.06 \\
2\end{array}$ & 0.098 & $\begin{array}{l}0.58 \\
6\end{array}$ & $\begin{array}{l}0.55 \\
8\end{array}$ & Rejected \\
\hline
\end{tabular}

The outcome of a hypothesis test running SEM is presented in Table 5 above. Firstly, the researchers assume that the store layout and the intention of purchase have a positive and significant association. A significant and positive relation was observed in Table 5 ( $\beta=0.471$, $t=5.307, p<0.001$ ) between store layout and purchasing intention. There is, however, recognition of the hypothesis 1 . Secondly, researchers assume that the product display and the intention to purchase have a positive and significant connection. Table 5 indicates that the relationship between the display of the product and the intention to purchase is positive and significant $(ß=0.187, t=3.110, p<0.05)$. There is also recognition of hypothesis 2 . Third, the author assumes that the connection between colour \& lighting and the intention of purchasing is positive and significant. As can be seen from Table 5 , there has been a positive and significant link between colour \& lighting and purchasing intention $(\beta=0.293, t=4.133$, $p<0.001)$. Hypothesis 3 is also accepted. Fourthly, the author assumes that the connection between cleanliness and intention to purchase is positive and significant. The positive and significant relation between cleanliness and purchasing intention $(\beta=0.062, t=0.586, p>0.05)$ is found in Table 5. Hypothesis 4 is also accepted. 


\section{Conclusion}

For any retail business, strong visual merchandising is very critical. The main purpose of this study is to examine visual merchandising elements that drive an individual to buy from fashion shops. This study shows that the relationship between the store layout and consumer purchasing intentions is positive and significant. It would also affect buyer buying intentions if the attributes of the shop are increased or decreased. Then there is also a constructive and important link between the show and the purchase intention of consumers. This means that any growth or decline in the product display attribute would influence the intention to purchase. In addition, the connection between colour \& lighting and the intentions to purchase is positive and significant. This would influence customer buying intentions if there is any rise or decline in colour and lighting. There is also no favourable association between cleanliness and the intention to purchase. This does not change customer purchases intention by increasing or decreasing the cleanliness attribute. Every industry wants different advertising strategy in order to get competitive business, which is necessary to adapt to different consumer needs. Market segmentation is the most common strategic targeting strategy for consumer diversity. The segmentation of the industry based on sex and age is very significant in fashion stores. For all fashion shops, thus, visual merchandising elements are very relevant.

\section{Research Limitations and Further Studies}

As other research, this study has a number of limitations. This research was concentrated only on the fashion shops to achieve results. For study results only cross-sectional data is used. Just one town has been selected for data collection. This research used the quantitative approach. In the future research the longitudinal data should be focused and would show more exact results. The future research relies on both quality and quantity. Two or three sample cities should be covered in the future. GEN Z for students for buying purposes may be used as part of the potential report.

\section{References}

Abdul Latiff, Z. A. B., Rezai, G., Mohamed, Z., \& Amizi Ayob, M. (2016). Food labels' impact assessment on consumer purchasing behavior in Malaysia. Journal of food products marketing, 22(2), 137-146.

Alawadhi, A., \& Yoon, S. Y. (2016). Shopping behavioral intentions contributed by store layout and perceived crowding: An exploratory study using computer walk-through simulation. Journal of Interior Design, 41(4), 29-46.

Ariffin, H. F., Bibon, M. F., \& Abdullah, R. P. S. R. (2017). Restaurant's Atmospheric Elements: What the customer wants. Journal of ASIAN Behavioural Studies, 2(3), 85-94.

Bashir, A. M., Bayat, A., Olutuase, S. O., \& Abdul Latiff, Z. A. (2019). Factors affecting consumers' intention towards purchasing halal food in South Africa: a structural equation modelling. Journal of Food Products Marketing, 25(1), 26-48.

Behera, M. P., \& Mishra, V. (2017). Impact of store location and layout on consumer purchase behavior in organized retail. Anvesha, 10(1), 10-21.

Bhattacharjee, A. M. I. T. A. B., Polas, M. R. H., \& Rahman, M. L. (2018). Challenges and prospects of tourism in Cox's bazar: An empirical study. Journal of Business and Technology (Dhaka), 13, 63-82. 
Bhattacharjee, A., Polas, M.R.H., Ahmed, M., and Eshita, K.F. (2020). "Alternative Concern on the Remittance Increases Investments and Financial Sustainability", IIUB Studies, A Multidisciplinary Research Journal, Vol. 2, No.1, pp. 29-46.

Bhatti, K. L., \& Latif, S. (2014). The impact of visual merchandising on consumer impulse buying behavior. Eurasian Journal of Business and Management, 2(1), 24-35.

Borisuit, A., Linhart, F., Scartezzini, J. L., \& Münch, M. (2015). Effects of realistic office daylighting and electric lighting conditions on visual comfort, alertness and mood. Lighting Research \& Technology, 47(2), 192-209.

Cant, M. C., \& Hefer, Y. (2014). Visual merchandising displays effect-or not-on consumers: the predicament faced by apparel retailers. Journal of Business and Retail Management Research, 8(2).

Cant, M. C., \& Wiid, J. A. (2020). Visual Merchandising Elements: Drivers Of Retail Strategies?. Journal of Applied Business Research (JABR), 36(5), 197-204.

Cohen, J. (1988). Statistical power analysis for the behavioral sciences. Second Edition. Hillsdale, NJ: Lawrence Erlbaum Associates, Publishers.

Choshaly, S. H. (2017). Consumer perception of green issues and intention to purchase green products. International Journal of Management, Accounting and Economics, 4(1), 6679.

Dash, M., \& Akshaya, L. (2016). A study on the impact of visual merchandising on impulse purchase in apparel retail stores. International Journal of Marketing and Business Communication, 5(2), 37-44.

De Korte, E. M., Spiekman, M., Hoes-van Oeffelen, L., van der Zande, B., Vissenberg, G., Huiskes, G., \& Kuijt-Evers, L. F. (2015). Personal environmental control: effects of preset conditions for heating and lighting on personal settings, task performance and comfort experience. Building and Environment, 86, 166-176.

Dhurup, M., \& Mafini, C. (2015). Finding empirical synergy between athlete-endorser brandfit, brand association and brand purchase intentions management. African Journal for Physical Health Education, Recreation and Dance, 21(1.1), 186-196.

Elbers, T. (2016). The effects of in-store layout-and shelf designs on consumer behaviour. Wageningen University \& Research, 1-22.

Figueiro, M. G., Nagare, R., \& Price, L. L. A. (2018). Non-visual effects of light: How to use light to promote circadian entrainment and elicit alertness. Lighting Research \& Technology, 50(1), 38-62.

Findling, M. T. G., Werth, P. M., Musicus, A. A., Bragg, M. A., Graham, D. J., Elbel, B., \& Roberto, C. A. (2018). Comparing five front-of-pack nutrition labels' influence on consumers' perceptions and purchase intentions. Preventive medicine, 106, 114-121.

Gigoła, M. (2014). Impact of Visual Merchandising on Consumers' Behaviour while Buying Apparels. Konsumpcja i Rozwój, 2, 73-83.

Gudonavičienè, R., \& Alijošienè, S. (2015). Visual merchandising impact on impulse buying behaviour. Procedia-Social and Behavioral Sciences, 213, 635-640.

Hefer, Y., \& Nell, E. C. (2015). Creating a store environment that encourages buying: a study on sight atmospherics. Journal of Governance and Regulation, 4(4), 471-475.

Harris, F., Roby, H., \& Dibb, S. (2016). Sustainable clothing: challenges, barriers and interventions for encouraging more sustainable consumer behaviour. International Journal of Consumer Studies, 40(3), 309-318.

Hsu, C. L., Chang, C. Y., \& Yansritakul, C. (2017). Exploring purchase intention of green skincare products using the theory of planned behavior: Testing the moderating effects of 
country of origin and price sensitivity. Journal of Retailing and Consumer Services, 34 , 145-152.

Hefer, Y., \& Cant, M. C. (2013). Visual Merchandising Displays Effect On Consumers: A Valuable Asset Or An Unnecessary Burden For Apparel Retailers. International Business \& Economics Research Journal (IBER), 12(10), 1217-1224.

Hefer, Y., \& Nell, E. C. (2015). Creating a store environment that encourages buying: a study on sight atmospherics. Journal of Governance and Regulation, 4(4), 471-475.

Hussain, R., \& Ali, M. (2015). Effect of store atmosphere on consumer purchase intention. International Journal of Marketing Studies, 7(2).

Iberahim, H., Zulkurnain, N. A. Z., Raja Ainal Shah, R. N. A., \& Rosli, S. Q. (2019). Visual merchandising and customers' impulse buying behavior: a case of a fashion specialty store. International Journal of Service Management and Sustainability (IJSMS), 4(1), 1-24.

Iberahim, H., Zureena, Z. N. A., Adila, R. R. N., \& Quraisyiah, R. S. (2018). Determinants of Customer Impulse Buying Behavior at Product Specialist Fashion Retail Stores. Journal of Economic \& Management Perspectives, 12(1), 538-544.

Imelia, R., \& Ruswanti, E. (2017). Factors affecting purchase intention of electronic house wares in Indonesia. International journal of business and management invention, 6(2), 37-44.

Jain, S. (2019). Factors affecting sustainable luxury purchase behavior: A conceptual framework. Journal of International Consumer Marketing, 31(2), 130-146.

Jones, N., \& Bartlett, H. (2018). The impact of visual impairment on nutritional status: A systematic review. British Journal of Visual Impairment, 36(1), 17-30.

Katrandjiev, H., \& Velinov, I. (2014). Investigation of Online Visual Merchandising (OVM) Elements of Apparel Web Stores. Economic Alternatives, (1), 84-98.

Kpossa, M. R., \& Lick, E. (2020). Visual merchandising of pastries in foodscapes: The influence of plate colours on consumers' flavour expectations and perceptions. Journal of Retailing and Consumer Services, 52.

Lee, J., \& Lee, J. N. (2015). How purchase intention consummates purchase behaviour: the stochastic nature of product valuation in electronic commerce. Behaviour \& Information Technology, 34(1), 57-68.

Lee, H., \& Lee, E. (2021). Effects of coloured lighting on pleasure and arousal in relation to cultural differences. Lighting Research \& Technology, 1477153521999592.

Li, Z. F., Deng, S., \& Moutinho, L. (2015). The impact of experience activities on tourist impulse buying: An empirical study in China. Asia Pacific Journal of Tourism Research, 20(2), 191-209.

Loan, K. T. M., Fah, B. C. Y., \& Samadi, B. (2015). Exploring customer purchasing intention over online store. International Journal of Business and Social Research, 5(5), 15-23.

Malik, G., \& Guptha, A. (2014). Impact of celebrity endorsements and brand mascots on consumer buying behavior. Journal of Global Marketing, 27(2), 128-143.

Maharani, N., Helmi, A., Mulyana, A., \& Hasan, M. (2020, March). Purchase intention of private label products as the impact of visual merchandising and customer value. In 2nd Social and Humaniora Research Symposium (SoRes 2019) (pp. 461-464). Atlantis Press.

Massara, F. (2020). A Work-Fun Model of Shopping Behaviour: Explaining When Consumers Buy on Impulse. Multidisciplinary Business Review, 13(2), 1-16. 
Mehta, D., \& Chugan, P. K. (2014). Impact of visual merchandising on consumer behavior: A study of furniture outlets. Universal Journal of Management, Horizon Research Publishing Corporation, Alhambra, CA, USA, 2(6), 207-217.

Mehta, N., \& Chugan, P. K. (2019). Visual Merchandising and Consumer Demography: The Impact on Impulse Buying Behavior. Business, Economy and Environment: Corporate Perspectives", Eds. Parag Rijwani, Samik Shome and Deepak Danak, Himalaya Publishing House, Mumbai for Institute of Management, Nirma University, Ahmedabad, 253-268.

Nasim, S., \& Shamshir, M. (2018). Consumer Behavior Towards Shopping Malls: A Systematic Narrative Review. IBT Journal of Business Studies (JBS), 14(1).

Nell, E. C. (2017). The impact of sensory environments on consumer buying behaviour: A study of visual displays and sight atmospherics. Journal of Business and Retail Management Research, 11(2).

Pandharipande, A., \& Newsham, G. R. (2018). Lighting controls: Evolution and revolution. Lighting Research \& Technology, 50(1), 115-128.

Park, M. S., Shin, J. K., \& Ju, Y. (2014). The effect of online social network characteristics on consumer purchasing intention of social deals. Global Economic Review, 43(1), 25-41.

Park, H. H., Jeon, J. O., \& Sullivan, P. (2015). How does visual merchandising in fashion retail stores affect consumers' brand attitude and purchase intention?. The International Review of Retail, Distribution and Consumer Research, 25(1), 87-104.

Park, H. H., Jeon, J. O., \& Sullivan, P. (2015). How does visual merchandising in fashion retail stores affect consumers' brand attitude and purchase intention?. The International Review of Retail, Distribution and Consumer Research, 25(1), 87-104.

Parsons, A. G., \& Descatoires, E. (2016). Retail marketing: A novel research agenda. Australasian Marketing Journal (AMJ), 24(2), 102-107.

Polas, M. R. H., Reza, M. M. U., \& Rowza, S. (2017). Role of advertising and service quality on tourism development in Bangladesh. IOSR Journal of Business and Management, 19(9), 77-86.

Polas, M. R. H., Jahanshahi, A. A., \& Rahman, M. L. (2018a). Islamic branding as a tool for customer retention: Antecedents and consequences of islamic brand loyalty. International Journal of Islamic Marketing and Branding, 3(1), 1-14.

Polas, M. R. H., Rahman, M. M., Miah, M. A., \& Hayash, M. M. A. (2018b). The impact of waiting time towards customers satisfaction in fast food establishments: Evidence from Bangladesh. IOSR Journal of Business and Management, 20(5), 11-21.

Polas, M. R. H., \& Jahanshahi, A. (2020). The effects of individual characteristics on women intention to become social entrepreneurs?.Journal of Public Affairs, e2204. https://doi.org/10.1002/pa.2204

Polas, M. R. H., Raju, V., Hossen, S. M., Karim, A. M., \& Tabash, M. I. (2020). Customer's revisit intention: Empirical evidence on Gen-Z from Bangladesh towards halal restaurants. Journal of Public Affairs, e2572. https://doi.org/10.1002/pa.2572

Polas, M. R. H., \& Raju, V. (2021). Technology and entrepreneurial marketing decisions during COVID-19. Global Journal of Flexible Systems Management, 22(2), 95-112.

Polas, M. R. H., Raju, V., Muhibbullah, M., and Tabash, M. I. (2021), "Rural women characteristics and sustainable entrepreneurial intention: a road to economic growth in Bangladesh", Journal of Enterprising Communities: People and Places in the Global Economy. https://doi.org/10.1108/JEC-10-2020-0183 
Rahmawati, N. A., Suroso, A. I., \& Ramadhan, A. (2018). Factors Influencing The Purchase Intention in Online Organic Fruit and Vegetable Stores. Jurnal Manajemen \& Agribisnis, 15(3), 209-209.

Rahim, A., Safin, S. Z., Kheng, L. K., Abas, N., \& Ali, S. M. (2016). Factors influencing purchasing intention of smartphone among university students. Procedia Economics and Finance, 37, 245-253.

Rathee, V., \& Prakash, C. (2017). Influence of Visual Merchandising on Customer Buying Decision-A Review of Literature Approach. World Wide Journal of Multidisciplinary Research and Development, 3(12), 103-105.

Sarwar, M. A., Awang, Z., Habib, M. D., Nasir, J., \& Hussain, M. (2020). Why did I buy this? Purchase regret and repeat purchase intentions: $A$ model and empirical application. Journal of Public Affairs, e2357.

Shaouf, A., Lü, K., \& Li, X. (2016). The effect of web advertising visual design on online purchase intention: An examination across gender. Computers in Human Behavior, 60, 622-634.

Shamsher, R. (2016). Store image and its impact on consumer behaviour. Elk Asia Pacific Journal of Marketing and Retail Management, 7(2), 1-27.

Singh, P., Katiyar, N., \& Verma, G. (2014). Retail shoppability: the impact of store atmospherics \& store layout on consumer buying patterns. International journal of scientific \& technology research, 3(8), 15-23.

Štulec, I., Petljak, K., \& Kukor, A. (2016). The role of store layout and visual merchandising in food retailing. European Journal of Economics and Business Studies, 2(1), 138-151.

Syahrivar, J. (2017). The Influence of Promotion Approach and Store Layout on Impulse Buying Behavior. FIRM Journal of Management Studies, 1(2).

Thomas, A. K., Louise, R., \& Vipinkumar, V. P. (2018). Impact of visual merchandising, on impulse buying behavior of retail customers. International Journal for Research in Applied Science and Engineering Technology, 6(2), 474-491.

Van Niekerk, B. M., Petzer, D. J., \& De Beer, L. T. (2016). The interrelationships between boutique store atmosphere, customer satisfaction, store loyalty and repurchase intention-A Study of Females in the North-West Province. The Retail and Marketing Review, 12(1), 70-88.

Widyastuti, P. (2018). Does visual merchandising, store atmosphere and private label product influence impulse buying? Evidence in Jakarta. Journal of Business and Retail Management Research, 12(3).

Wilson, N., Keni, K., \& Tan, P. H. P. (2019). The effect of website design quality and service quality on repurchase intention in the e-commerce industry: A cross-continental analysis. Gadjah Mada International Journal of Business, 21(2), 187-222.

Yan, D., Sengupta, J., \& Hong, J. (2016). Why does psychological distance influence construal level? The role of processing mode. Journal of Consumer Research, 43(4), 598-613.

Yaoyuneyong, G., Foster, J. K., \& Flynn, L. R. (2014). Factors impacting the efficacy of augmented reality virtual dressing room technology as a tool for online visual merchandising. Journal of Global Fashion Marketing, 5(4), 283-296.

Yildirim, K., Cagatay, K., \& Ayalp, N. (2015). Effect of wall colour on the perception of classrooms. Indoor and Built Environment, 24(5), 607-616.

Yim, M. Y. C., Yoo, S. C., Sauer, P. L., \& Seo, J. H. (2014). Hedonic shopping motivation and coshopper influence on utilitarian grocery shopping in superstores. Journal of the Academy of Marketing Science, 42(5), 528-544. 
Khaled, A. S., Ahmed, S., Tabash, M. I., Al-Homaidi, E. A., \& Hossain, M. I. (2019). The Impact of Technological and Marketing Innovations on Retailing Industry: Evidence of India. Journal of Reviews on Global Economics, 8, 948-957 